\title{
The history of subaquatic volcanism recorded in the sediments of Lake Kivu; East Africa
}

\author{
Kelly Ann Ross • Martin Schmid • \\ Sandra Ogorka • Fabrice A. Muvundja • \\ Flavio S. Anselmetti
}

Received: 3 October 2013/Accepted: 15 April 2015/Published online: 8 May 2015

(C) Springer Science+Business Media Dordrecht 2015

\begin{abstract}
Subaquatic volcanic activity has been ongoing in Lake Kivu since the early Holocene and has a dynamic effect on the biological productivity in the surface water, and the preservation of carbonate in the deep anoxic water. Groundwater discharge into the lake's deepwater propels the upward advection of the water column that ultimately supplies nutrients to the surface water for biological production. The amount of nutrients supplied from the deepwater can be increased suddenly by (1) a cold meteorological event that drives deep seasonal mixing resulting in increased nutrients from below and oxygen from above, or (2) subaquatic volcanic activity that induces a buoyant hydrothermal plume, which entrains nutrients from the
\end{abstract}

Electronic supplementary material The online version of this article (doi:10.1007/s10933-015-9842-6) contains supplementary material, which is available to authorized users.

K. A. Ross $(\square) \cdot$ M. Schmid · S. Ogorka

F. A. Muvundja F. S. Anselmetti

Department of Surface Waters - Research and

Management Eawag, Swiss Federal Institute of Aquatic

Science and Technology, CH-6047 Kastanienbaum,

Switzerland

e-mail: kellyann.ross@gmail.com

M. Schmid

e-mail: martin.schmid@eawag.ch

\section{K. A. Ross}

Institute of Biogeochemistry and Pollutant Dynamics

ETH, Swiss Federal Institute of Technology,

CH-8092 Zurich, Switzerland deepwater and results in anoxia or suboxic conditions in the surface water. Previous sedimentological studies in Lake Kivu have hypothesized that regional climatic changes are responsible for sudden changes in the preservation of carbonates in the Main Basin. Here we reveal that sublacustrine volcanic events most likely induce the abrupt changes to the geochemistry in the sediment in Lake Kivu. An unprecedented look into the sediment stratigraphy and geochemistry from high-resolution seismic-reflection, and ${ }^{15} \mathrm{~N}$-isotope analyses was conducted in the Main Basin. The results reveal that buoyant hydrothermal plumes caused by subaquatic volcanic activity are a possible trigger for increased biological productivity and organic matter preservation, and that ongoing hydrothermal activity increases the alkalinity in the deepwater, leading to carbonate preservation. The onset of carbonate preservation since the 1970s that is currently observed in the

\footnotetext{
F. A. Muvundja

Unité d'Enseignement et de Recherche en Hydrobiologie Appliquée (UERHA), Département de Biologie-Chimie Institut Supérieur Pédagogique de Bukavu (ISP Bukavu), BP 854 Bukavu, Democratic Republic of the Congo

F. A. Muvundja

Laboratory of Freshwater Ecology, URBE, Department of Biology, University of Namur, 5000 Namur, Belgium

F. S. Anselmetti

Institute of Geological Sciences and Oeschger Centre for Climate Change Research, University of Bern,

CH-3012 Bern, Switzerland
} 
sediment could indicate that hydrothermal discharge has recently increased in the lake.

Keywords XRF $\cdot{ }^{15} \mathrm{~N} \cdot$ Lake sediment $\cdot$ Subaquatic volcanism · Limnic eruption · High-resolution seismic

\section{Introduction}

Lake Kivu is a dynamic system that has been heavily influenced by volcanic activity since its development in the Miocene (Ross et al. 2014). Phreatomagmatic cones border the northern shoreline, and are reminiscent of lavas of the Viruga Volcanic Province (VVP) that have dammed the northern outflow of the lake sometime in the late Pleistocene $\sim 10-14$ ka (Haberyan and Hecky 1987). Furthermore, the sublacustrine basin is marred by submerged volcanic features, which include volcanic domes, edifices, lava flows, and tuff cones (Ross et al. 2014). The lake-damming resulted in an $\sim 400$-m lake-level rise that eventually drained south to Lake Tanganyika via the Ruzizi River (Degens et al. 1973; Ross et al. 2014). It was following this blockage that Lake Kivu's thermohaline stratification was initiated as a result of ongoing hydrothermal activity in its deepwater. Since then, at least two periods are described where there has been a possible breakdown of the stratification linked to intense hydrothermal activity and volcanism within the last $\sim 10 \mathrm{kyr}$ (Haberyan and Hecky 1987), likely causing a degassing of the lake's deepwater. A similar eruption from the present-day lake would cause significant and detrimental damage to the riparian population, including the two million people living along the shorelines of Lake Kivu.

Presently the lake is meromictic with seasonal mixing in the top $\sim 65 \mathrm{~m}$, referred to as the mixolimnion. The monimolimnion is the thermohaline-stratified anoxic water that persists below this depth. It is separated from the mixolimnion by a steep salinity gradient. The stable stratification in the monimolimnion is maintained by warm and salty subaquatic groundwater discharge (SGD), or simply hydrothermal springs (Ross et al. 2015). Major density gradients are observed within the monimolimnion that are maintained at their depths by relatively cold SGD into the lake above the respective gradients (Ross et al. 2015). Observations reveal only small changes in temperature and conductivity in the monimolimnion since the 1970s, indicating that these properties are currently near steady state. Nevertheless, they also indicate that ongoing warm SGD has been lifting the lower boundaries of the density gradients (Schmid et al. 2012). The cumulative SGD displaces the lake water upwards at vertical advection rates of 0.15 0.9 myear $^{-1}$ without disturbing the permanent stratification (Schmid et al. 2005).

It is estimated from the calculated advection rates that the monimolimnion has persisted without complete mixing for $\sim 1000$ years (Schmid et al. 2005), and has been accumulating dissolved $\mathrm{CO}_{2}$ and $\mathrm{CH}_{4}$ during this period. SGD is the main source of $\mathrm{CO}_{2}$, whereas $\mathrm{CH}_{4}$ is a result of ongoing methanogenesis (Schoell et al. 1988; Pasche et al. 2011). $\mathrm{CO}_{2}$ and $\mathrm{CH}_{4}$ would erupt from the monimolimnion, and consequently mix the lake, if the combined partial pressure of these gases were to exceed the hydrostatic pressure of the lake at all depths (presently at a maximum of $55 \%$ saturation). The gases could also hypothetically erupt from the lake if subaquatic volcanic activity were significant enough to create a large thermal plume and induce gas oversaturation (Schmid et al. 2003). Degens and Kulbicki (1973) suggested that the lake was mixed at the onset of intense hydrothermal activity $\sim 5 \mathrm{ka}$, and then possibly again at $\sim 1 \mathrm{ka}$. The youngest lake-mixing event correlates well with the estimated minimum age of the monimolimnion calculated by Schmid et al. (2005). However, there is still a paucity of data that indicates a lake eruption has occurred in the past. Furthermore, there is no information that correlates a lake eruption to either gas oversaturation or subaquatic volcanic activity.

The mixolimnion as its own entity behaves similarly to other tropical lakes; a thermal stratification develops during the rainy season and complete mixing occurs during the dry season. A stable thermal stratification persists in the mixolimnion of Lake Kivu from September to June that separates it into an epilimnion where most of the primary production occurs, and a hypolimnion that becomes increasingly anoxic. The thermal stratification is obliterated in the dry season, which typically begins in June and ends in August. During the dry season the surface waters are cooled down by a low relative humidity, an increase in evaporation, strong winds, and a lower intensity of downward long-wave radiation as a result of reduced 
cloud coverage (Schmid and Wüest 2012). These factors culminate in convective mixing down to a maximum depth of $65 \mathrm{~m}$. The strong, permanent thermohaline stratification at the top of the monimolimnion prevents deeper seasonal mixing. The stratification in the deepwater of e.g. Lakes Malawi and Tanganyika is much weaker. Vertical exchange of solutes by turbulent transport in these lakes is therefore more dominant compared to Lake Kivu (Verburg et al. 2003), where upwelling by advection is the dominant process of solute exchange.

Nutrients have been accumulating for thousands of years in the monimolimnion of Lake Kivu as a result of its persistent thermohaline stratification. Most of the settling organic matter $(\mathrm{OM})$ from biological production in the mixolimnion is mineralized at the sediment-water interface. Therefore, nutrients continue to accumulate in the anoxic water, and are only supplied to the mixolimnion by the upward advection of the water column and the downward seasonal mixing. The contribution of dissolved inorganic phosphorous (DIP) and $\mathrm{NH}_{4}^{+}$from the monimolimnion to the mixolimnion in Lake Kivu presently accounts for 80 and $85 \%$, respectively, of the total nutrient inputs used for biological production (Pasche et al. 2009). The high $\mathrm{C}: \mathrm{P}$ and $\mathrm{N}: \mathrm{P}$ ratios measured from the seston in the mixolimnion indicate that the supply of DIP is limiting primary production (Sarmento et al. 2006), while the $\mathrm{C}: \mathrm{N}$ ratios also indicate moderate $\mathrm{N}$ limitation (Sarmento et al. 2012). Primary production is dominantly cyanobacteria in the rainy season, and pennate diatoms and cryptophytes in the dry season (Sarmento et al. 2012). Seasonal and interannual variations in biological production, including phytoplankton growth, are dependent on changes to the seasonal mixing depth. This is because the SGD is near steady-state, and therefore upwelling yields a constant rate of supply of nutrients to the bottom of the mixolimnion. High productivity occurs in the dry season when deeper mixing supplies nutrients from the monimolimnion. A low productivity persists throughout the rainy season with a stable thermal stratification in the mixolimnion and therefore a reduced nutrient supply (Darchambeau et al. 2014).

Exceptional mixing events will increase the supply of nutrients from the monimolimnion and fuel a higher productivity. These changes in nutrient dynamics are recorded in the form of anomalous sediment layers that consequently yield information on past climate conditions that have altered the seasonal mixing depth, or past lake eruptions and subaquatic volcanic activity that might have eliminated the thermohaline stratification and entrained nutrients from below. The present study investigates the sediment stratigraphy, lithology, and geochemistry in the Main Basin in order to disentangle changes in nutrient dynamics as a consequence of climate change, from past lake eruptions and subaquatic volcanic activity.

\section{Study site}

Lake Kivu is situated at an elevation of $1463 \mathrm{~m}$ above sea level within the western branch of the East African Rift system. It has a 1:2 area, ratio of lake-water $\left(2385 \mathrm{~km}^{2}\right)$ to watershed $\left(4940 \mathrm{~km}^{2}\right)$. The lake volume is $549 \mathrm{~km}^{3}$, and a total of $300 \mathrm{~km}^{3}$ at standard temperature and pressure of $\mathrm{CO}_{2}$, and $60 \mathrm{~km}^{3}$ at standard temperature and pressure of $\mathrm{CH}_{4}$, are dissolved in the monimolimnion (Schmid et al. 2005). The presence of subaquatic volcanic features, where active hydrothermal springs are observed, has been outlined by a previous study (Ross et al. 2014), and their location is delineated in Fig. 1. In the Holocene, a large lake-level rise followed the increased volcanic activity of the Nyiragongo chain to the north and the onset of wetter climatic conditions (Ross et al. 2014).

The hydroclimate in tropical East Africa varies considerably on all time-scales (Russell and Johnson 2005, 2007). Zonal shifts in the Intertropical Convergence Zone are often accountable for the observed spatial and interannual variability of rainfall. When considering longer time-scales, variations in the sea surface temperature gradient across the Indian Ocean are suggested to be the principal controller of multidecadal variability (Tierney et al. 2013). Recent hydroclimate data indicates drought-like conditions within the last two decades in this region that is also recorded in the Kivu Basin, albeit with considerable interannual fluctuations (Muvundja et al. 2014). Major drought events of decadal, centennial, and millennial-scale duration have been recorded in the lacustrine records in Lake Edward, Tanganyika, Malawi and Victoria (Tierney et al. 2010; Stager et al. 2005, 2009; Brown and Johnson 2005; Powers 
Fig. 1 Overview map of Lake Kivu. The inset is the location of the Kivu Basin within Africa, and reveals its proximity to other lakes within the Western Rift. Gray scale bathymetric map is overlain by contour lines with a $50 \mathrm{~m}$ vertical distance. Cores used for analysis are marked directly onto the map

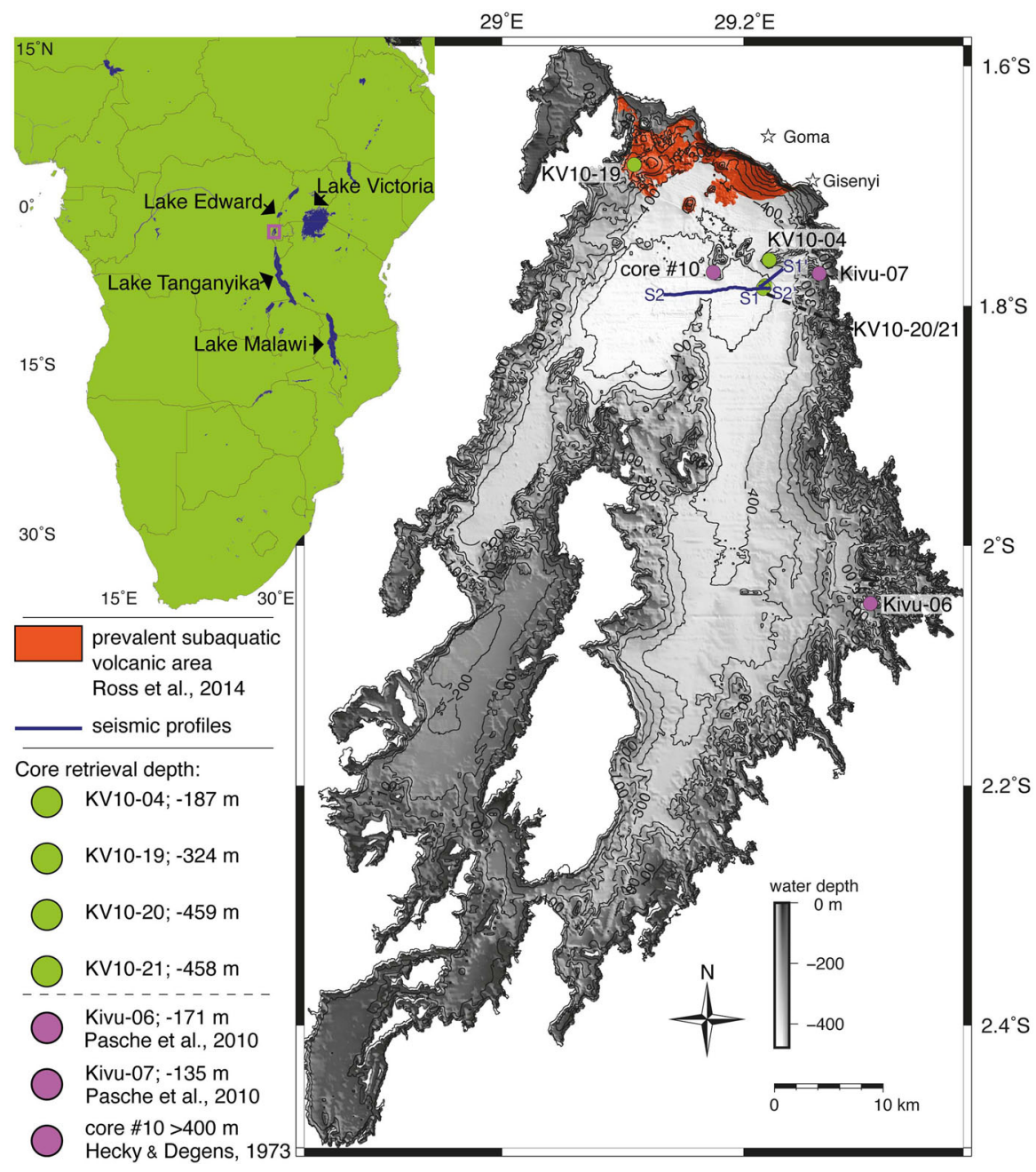

interpretation was performed with the SMT Kingdom Suite software.

Sediment parameters

\section{Materials and methods}

Geophysical surveys

Seismic stratigraphic analysis of the shallow subsurface sediment stratigraphy down to a depth of $\sim 10 \mathrm{~m}$ was achieved using $3.5 \mathrm{kHz}$ pinger single-channel data acquired in October, 2010. The system was mounted to the boat RV Gloria and the survey was conducted at an average speed of $2 \mathrm{~m} \mathrm{~s}^{-1}$ using a GPS navigation system. Processing included a flat gain and a bandpass filter $(1600-6000 \mathrm{~Hz})$. Seismic data
The locations of gravity cores given in Fig. 1 were chosen based on the seismic survey results, and the geomorphology presented in Ross et al. (2014). As a consequence of the high gas concentration in the monimolimnion leading to degassing upon pressure relief, complete undisturbed cores were only retrieved above $200 \mathrm{~m}$ water depth. The top sections of cores KV10-20 and -21 retrieved from 459 and $458 \mathrm{~m}$ depth, respectively, were lost from gas bubbling. The cores were scanned for petrophysical properties with a GEOTEK $^{\mathrm{TM}}$ multisensor core logger (MSCL) 
calibrated with an aluminium-water standard. The cores were then opened into half-sections and immediately photographed. The core-photographs were overexposed for easy visualization of the colour variations. Lithological successions were macroscopically described and smear-slide analysis were conducted on each section using a petrographic microscope with alternating plane and cross-polarized light.

The intensities of $\mathrm{Ca}, \mathrm{Fe}, \mathrm{S}, \mathrm{Mn}, \mathrm{Ti}$, and $\mathrm{Sr}$ were determined on half-cores using an X-ray fluorescence (XRF) core scanner (ITRAX, Cox Ltd., Sweden) with a Mo-tube at $30 \mathrm{kV}$ and $30 \mathrm{~mA}$ for cores KV10-04 and -21. Cores KV10-19 and -20 were scanned with an Avaatech XRF core scanner using a measurement duration of $20 \mathrm{~s}$ at $10 \mathrm{kV}$ and a $2000 \mu \mathrm{A}$ current for light elements, whereas $30 \mathrm{kV}$ and $1000 \mu \mathrm{A}$ were applied for the heavier elements. The scanning was conducted with an integration time of $10 \mathrm{~s}$ per measurement at a 2-mm resolution for KV10-04 and -21 , and at 5-mm for cores KV10-19 and -20, and the results are reported as counts.

Cores KV10-04 and -21 were sampled at $1-\mathrm{cm}$ intervals, and samples were taken from representative lithological sections in each core including KV10-19 and -20 . The samples were then subsequently frozen, lyophilized, and ground until homogeneous. Total carbon (TC), total nitrogen (TN) and the stable nitrogen isotope composition $\left({ }^{15} \mathrm{~N}\right)$ of the homogenized samples were analyzed with an elemental analyzer (EuroVector, Euro EA) linked by continuous flow to an isotope-ratio mass spectrometer (Micromass, IsoPrime). The ${ }^{15} \mathrm{~N}$ values were calibrated using international reference materials (IAEA-N1) with an assigned $\delta^{15} \mathrm{~N}$ value of $4 \%$ (versus AIR). The analytical reproducibility for ${ }^{15} \mathrm{~N}$ measurements was $\pm 0.37 \%{ }^{\circ}{ }^{15} \mathrm{~N}$ is reported as $(\delta)$ in units \%o according to Eq. 1:

$\delta^{15} \mathrm{~N}=\frac{R_{\text {sample }}-R_{\text {AIR }}}{R_{\text {AIR }}} 1000 \%$

Total inorganic carbon (TIC) was analyzed as $\mathrm{CO}_{2}$ on a CM 5012 Coulometer (UIC) following acidification with $\mathrm{HCl}(3 \mathrm{M})$. The precision for TIC was $\pm 0.4 \%$. Total organic carbon (TOC) was calculated from the difference of TC and TIC. Biogenic silica (BSi) was measured according to the methods described by Pasche et al. (2010) on two separate cores taken at the same location, where the cores were aligned based on their TIC profiles, and the duplicate core was sampled onsite.

\section{Chronology}

Cores KV10-04, -19, -20, and -21 taken from the Main Basin were sampled for terrestrial macrofossils in order to determine an age model for the system. The cores were aligned based on their lithology and patterns in XRF-derived $\mathrm{Ca}$ and $\mathrm{Zr}$ counts. The depth down to $9.5 \mathrm{~cm}$ in KV10-04 was dated using ${ }^{210} \mathrm{~Pb}$ and ${ }^{226} \mathrm{Ra}$ concentrations provided by Pasche et al. (2010) from Kivu-06 by applying the Constant Initial Concentration (CIC) model (Appleby and Oldfield 1978), and assuming the same depositional environment leading to similar sedimentation rates between the cores. The bottom $58 \mathrm{~cm}$ of KV10-04, and the portion of cores KV10-19, -20 , and -21 that were not disturbed by gas, were dated using ${ }^{14} \mathrm{C}$ ages of terrestrial organic material calibrated with the OxCal 4.2 program (Ramsey 2009). The metadata for radiocarbon analyses are found in ESM1.

\section{Results}

\section{Sedimentology}

Core KV10-04 was used in this study to describe the key sedimentary successions. Its location of origin and alignment to cores Kivu-06, -07 (Fig. 2), and core \#10 (Fig. 4) from preceding studies, make it an ideal core for analysing paleo-environmental changes. The sediment from KV10-04 is composed mainly of finely laminated carbonate- and organic-rich mud. The mmsized laminations consist of aragonite and diatoms, or $\mathrm{OM}$ and diatom frustules, in lithofacies $\mathrm{A}$ and $\mathrm{B}$, respectively (Fig. 4). These laminated sections are punctuated with the visible lithofacies; C, D, E, and F (Fig. 3). In addition to their different colours, these layers are also recognized by geochemical changes in Fig. 3, and the lithological changes observed in the smear slides in Fig. 4. They are characterized by a high diatom content for lithofacies $\mathrm{C}$, a high $\mathrm{OC}$ content for lithofacies $\mathrm{D}$, a mixture of diatoms and carbonates with traces of tephra for lithofacies E, and dominantly tephra material for lithofacies F. 


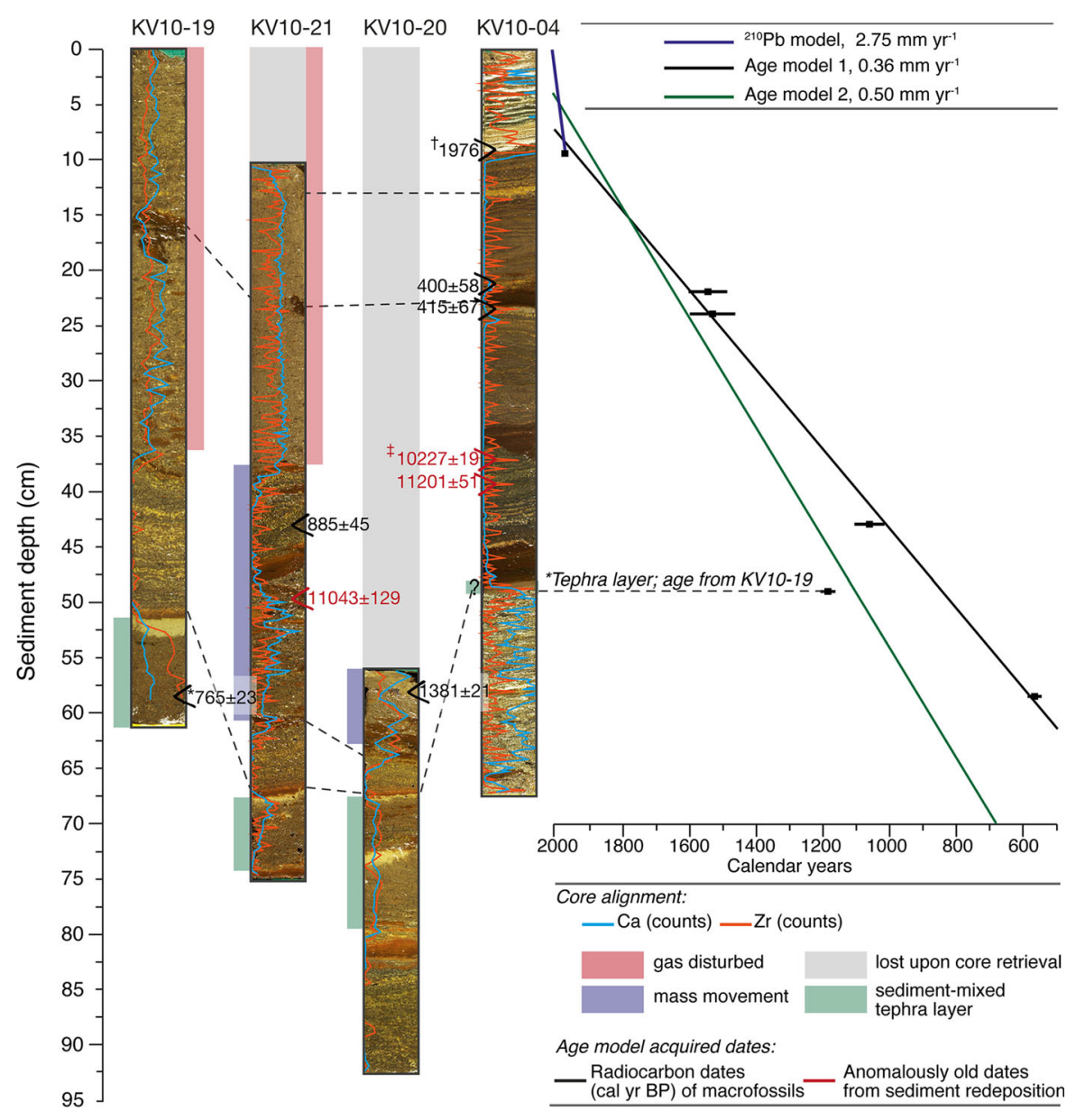

Fig. 2 Two age models are hypothesized following analyses of dates from all sediment cores: Age model 1 applies the radiocarbon ages from KV10-04, -20 , and -21 , and the ${ }^{210} \mathrm{~Pb}$ calculated age, Age model 2 applies the latter ${ }^{210} \mathrm{~Pb}$ age and three radiocarbon ages at 22 and $24 \mathrm{~cm}$ depth from KV10-04, and the age for the tephra layer at $49.5 \mathrm{~cm}$ depth taken from the sediment-mixed tephra in KV10-19 at $58 \mathrm{~cm}$ depth. Dagger symbol $(\dagger)$ is the age calculated from unsupported $\mathrm{Pb}$, and all

KV10-04 was taken on a ridge at $187 \mathrm{~m}$ water depth southeast of the area of subaquatic volcanic cones (Fig. 1). Based on its location, this core should be exempt from mass-movement deposits and sediment mobilization from a gas eruption in the Main Basin. The lithology in core KV10-04 is directly correlated to the lithology in cores Kivu-06 and -07 taken by Pasche et al. (2010), and core \#10 taken by Hecky and Degens (1973) (Fig. 1). Core KV10-21 is correlated to core KV10-04 by the layers C1 and D1 (Fig. 3), observed within the gas-disturbed portion of this core (Fig. 2). The sediment directly below this depth is not

other dates are in cal yrBP calculated using OxCal 4.2 (Ramsey 2009). Double dagger symbol ( $\$$ ) is taken from the corresponding depth in Kivu-07 (Pasche et al. 2010). The red dates are three anomalously old dates $>10$ cal kyr BP obtained in cores KV10-04, KV10-21 and Kivu-07, which were assumed to be reworked terrestrial plant macrofossils and therefore not considered in the calculation of the age models

correlatable to core KV10-04 due to a mass-movement deposit that is observed in Fig. 2. Cores KV10-20 and 21 can be correlated to core KV10-19 taken near the location of subaquatic volcanic features $15 \mathrm{~km}$ to the northwest (Fig. 1). The three cores each contain a mixed-sediment layer that consists of diatoms, carbonates, and traces of tephra, which are labeled 'tephra layer' in Fig. 2. The prominent tephra layer F1 is used to align KV10-04 with core \#10 taken by Hecky and Degens (1973) in 1972 (Fig. 4).

The sedimentation rate in the top $9.5 \mathrm{~cm}$ of core $\mathrm{KV} 10-04$ is high relative to the lower core-section as a 


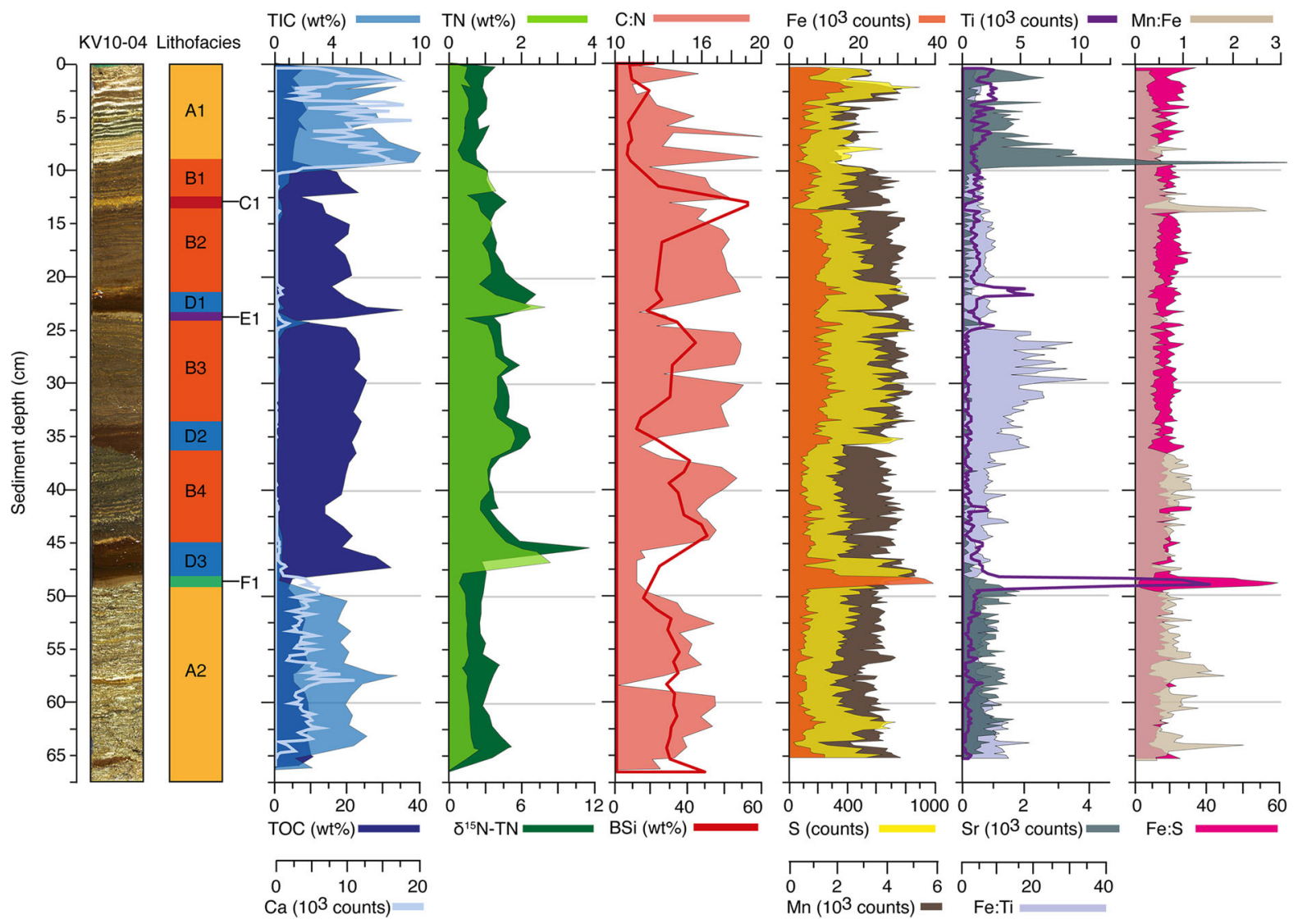

Fig. 3 Geochemical data from KV10-04. Geochemical parameters TIC, TOC, TN, and $\mathrm{BSi}$ in \% weight. Isotope data for ${ }^{15} \mathrm{~N}$. XRF data for Fe, S, Mn, Ti, and Sr in counts. Geochemical

direct effect of carbonate precipitation (Pasche et al. 2010). A linear sedimentation rate (LSR) of $2.75 \mathrm{~mm} \mathrm{year}^{-1}$ yields a calendar age of 1976 at $9.5 \mathrm{~cm}$ core depth (Fig. 2). This age was calculated to be at least 15 years younger than in previous age models that did not always include ${ }^{226} \mathrm{Ra}$ concentrations (Pasche et al. 2010). Age model 1 applies the 1976 age, in addition to four radiocarbon calibrated dates, to produce an age versus depth LSR of $0.36 \mathrm{~mm} \mathrm{year}^{-1}$. The 1976 age and the three radiocarbon dates used in Age model 2 yield a LSR of $0.5 \mathrm{~mm} \mathrm{year}^{-1}$ (Fig. 2). Age model 2 applies the radiocarbon age obtained within the tephra layer of core KV10-19. The younger age here implies that the calibrated ages from KV10-20 and -21 at 58.5 and 43 $\mathrm{cm}$ depth, respectively, were reworked to yield older ages. This scenario seems likely since the marcrofossil samples were taken from what appears to be a distal proxy data for SGD versus allochthonous input (Fe:Ti), abrupt changes to seasonal mixing depth ( $\mathrm{Mn}: \mathrm{Fe}$ ), and authigenic pyrite formation (Fe:S). The lithofacies legend is given in Fig. 4

mass-movement deposit, with visible coarse-grained mica flakes and shell fragments (Fig. 2). The rates presented in Fig. 2 are comparable to the ${ }^{14} \mathrm{C}$ derived LSR of $0.3 \mathrm{~mm}$ year $^{-1}$ provided by Hecky and Degens (1973) for the overlapping section of their core \#10 (Fig. 3).

\section{Geochemistry}

\section{XRF data}

The XRF counts for $\mathrm{Ca}, \mathrm{Fe}, \mathrm{S}, \mathrm{Mn}, \mathrm{Ti}$, and $\mathrm{Sr}$ in Fig. 3 represent most of the variation observed in the data of core KV10-04. Ca intensities correlate with TIC concentrations $(r=0.86)$, implying that $\mathrm{Ca}$ in the sediment is mostly bound to carbonates. Carbonate precipitation and preservation in Lake Kivu is controlled by (1) aragonite oversaturation in the 
Fig. 4 Core \#10 aligned with KV10-04 by layer R3/ $\mathrm{F} 1$. The colours in core \#10 are from the descriptions given in Hecky and Degens (1973), Degens et al. (1973), Stoffers and Hecky (1978), Degens and Kulbicki (1973), and Haberyan and Hecky (1987) that correspond to the lithology in KV10-04. Lithological colours and letters are represented by their corresponding smear slides with a scale bar of $50 \mu \mathrm{m}$ in each image

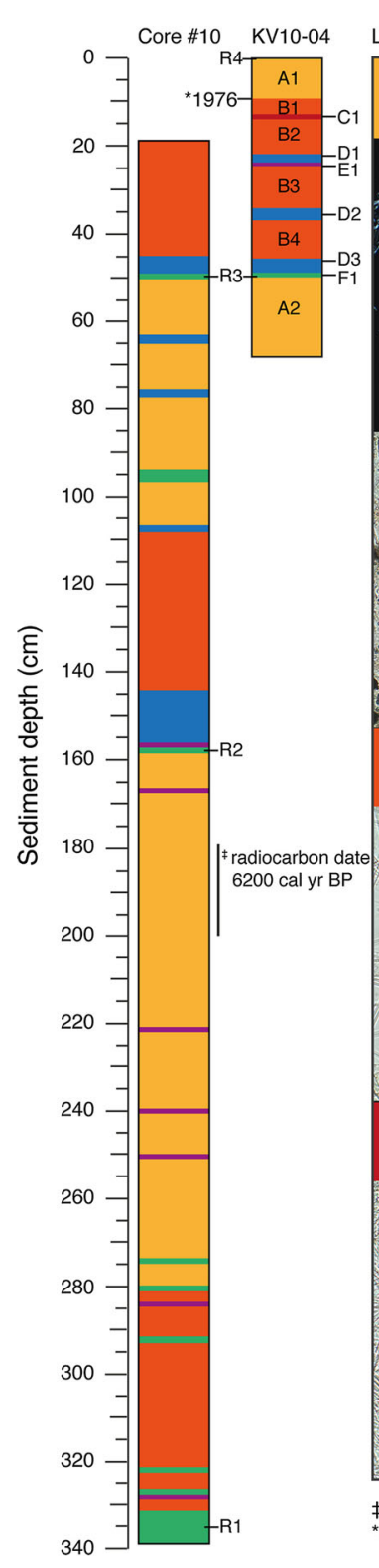

Lithofacies:

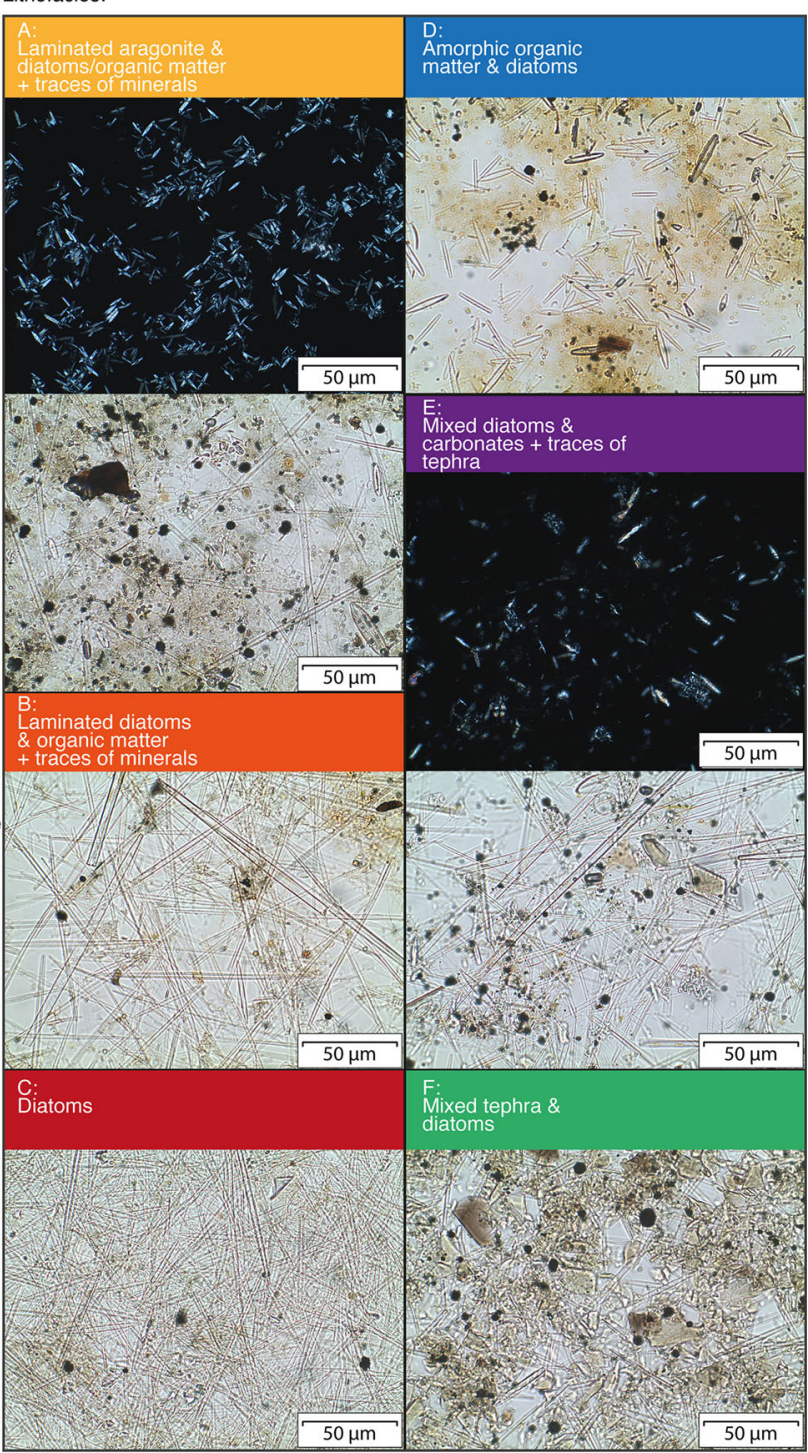

$\ddagger$ radiocarbon date of bulk organic matter; Hecky and Degens, 1973

*Hecky and Degens core taken prior to onset of carbonate at $10 \mathrm{~cm}$ sediment depth mixolimnion and (2) $\mathrm{Ca}^{2+}$ and $\mathrm{CO}_{3}^{2-}$ concentrations in the water column, which are further controlled by the $\mathrm{pH}$ and alkalinity (Ross et al. 2015). A similar trend to $\mathrm{Ca}$ is observed for $\mathrm{Sr}$, which is commonly exchanged for $\mathrm{Ca}$ in aragonite and therefore also primarily controlled by carbonate precipitation and dissolution. $\mathrm{Sr}$ in Lake Kivu is enriched in the hydrothermal SGD within the monimolimnion (Ross et al. 2015), and therefore large peaks in $\mathrm{Sr}$ could indicate increased hydrothermal discharge; e.g. the onset of layer A1 in Fig. 3.
The dissolved Fe, S, and Mn flux into Lake Kivu is primarily controlled by SGD (Ross et al. 2015). Fe correlates with S in KV10-04 ( $r=0.85)$ outside of the tephra layer F1, which suggests that Fe in Lake Kivu sediments is primarily present in the form of authigenic $\mathrm{Fe}$ sulfides. Mn does not correlate with $S$ to the same degree as $\mathrm{Fe}(\mathrm{r}=0.6)$, likely due to the higher solubility of $\mathrm{Mn}^{2+}$ compared to $\mathrm{Fe}^{2+}$ in the reducing waters of the monimolimnion (Ross et al. 2015). There is an overall increase in $\mathrm{Fe}$ and $\mathrm{S}$ relative to Mn beginning at layer $\mathrm{D} 2$, which lowers the general $\mathrm{Mn}$ :Fe ratio above this 
layer (Fig. 3). A peak in $\mathrm{Mn}^{2+}$ is observed just below the oxycline in the water column that is formed by the partial redissolution of $\mathrm{MnOOH}$ and $\mathrm{MnCO}_{3}$ precipitates from mixing in the dry season (Pasche et al. 2009). Under these concurrent conditions large peaks in $\mathrm{Mn}: \mathrm{Fe}$ in $\mathrm{KV} 10-04$ could represent peaks in $\mathrm{MnOOH}$ and $\mathrm{MnCO}_{3}$ precipitates, which are positively influenced by the depth of mixing in the dry season.

$\mathrm{Ti}$ is not susceptible to biogeochemical alterations in the water column or during diagenesis, and represents the influx of terrestrial and/or volcanic material into the lake (Vogel et al. 2013). The large peaks in Ti in KV10-04 are attributed to tephra layers, e.g. layer F1 and $\mathrm{E} 1 \mathrm{in} \mathrm{Fig}$. 3. Elevated Fe relative to Ti corresponds to lower inputs of allochthonous material or higher inputs of Fe from SGD (Ross et al. 2015). Therefore elevated Fe:Ti ratios, including that observed in layer B3 in Fig. 2, indicate the importance of authigenic $\mathrm{Fe}$ precipitation in Lake Kivu at certain periods. $\mathrm{K}$ revealed a nearly identical trend to $\mathrm{Ti}$ ( $r=0.98$; data not shown), which is likely an effect of the K-rich volcanics in the VVP (Smets et al. 2010).

\section{TOC/TIC/TN/BSi}

The aragonite-OM laminations in Fig. 3 are observed between 0 and $10 \mathrm{~cm}$, and again between 50 and
$67 \mathrm{~cm}$ depth in lithofacies A of KV10-04. The dilution of TOC by aragonite precipitation (Pasche et al. 2010), corresponds to the negative correlation in Fig. 5i $(r=-0.8)$. A high \% TOC found within lihtofacies D observed in Fig. 3 indicate a high OC production in the mixolimnion at the time of their deposition. These layers contain on average $1.5 x$ more OC content relative to the composition in lithofacies B.

Figure 5 ii in core KV10-04 $(r=0.93)$ yields an average $\mathrm{C}: \mathrm{N}$ ratio of 15 ( $\sigma 2.4)$, suggesting $\mathrm{OM}$ originates primarily from autochthonous biological production, which is also supported by the small catchment to lake ratio and the trophic status of the lake (Sarmento et al. 2012). Comparatively, the D lithofacies have a C:N ratio of $12(\sigma 0.8)$ that could indicate decreased $\mathrm{N}$-limitation in these layers. Troughs in the C:N ratio are observed at the depths of D1, D2 and D3 in Fig. 3.

The BSi measurements in KV10-04 reconstruct the phytoplankton abundance that is enriched in diatoms in the dry season. Nutrient fluxes into the mixolimnion from seasonal mixing is the most important parameter controlling diatom abundance (Sarmento et al. 2012). A large peak in BSi observed in layer $\mathrm{C} 1$ of Fig. 3 implies an increased mixing depth at this time.
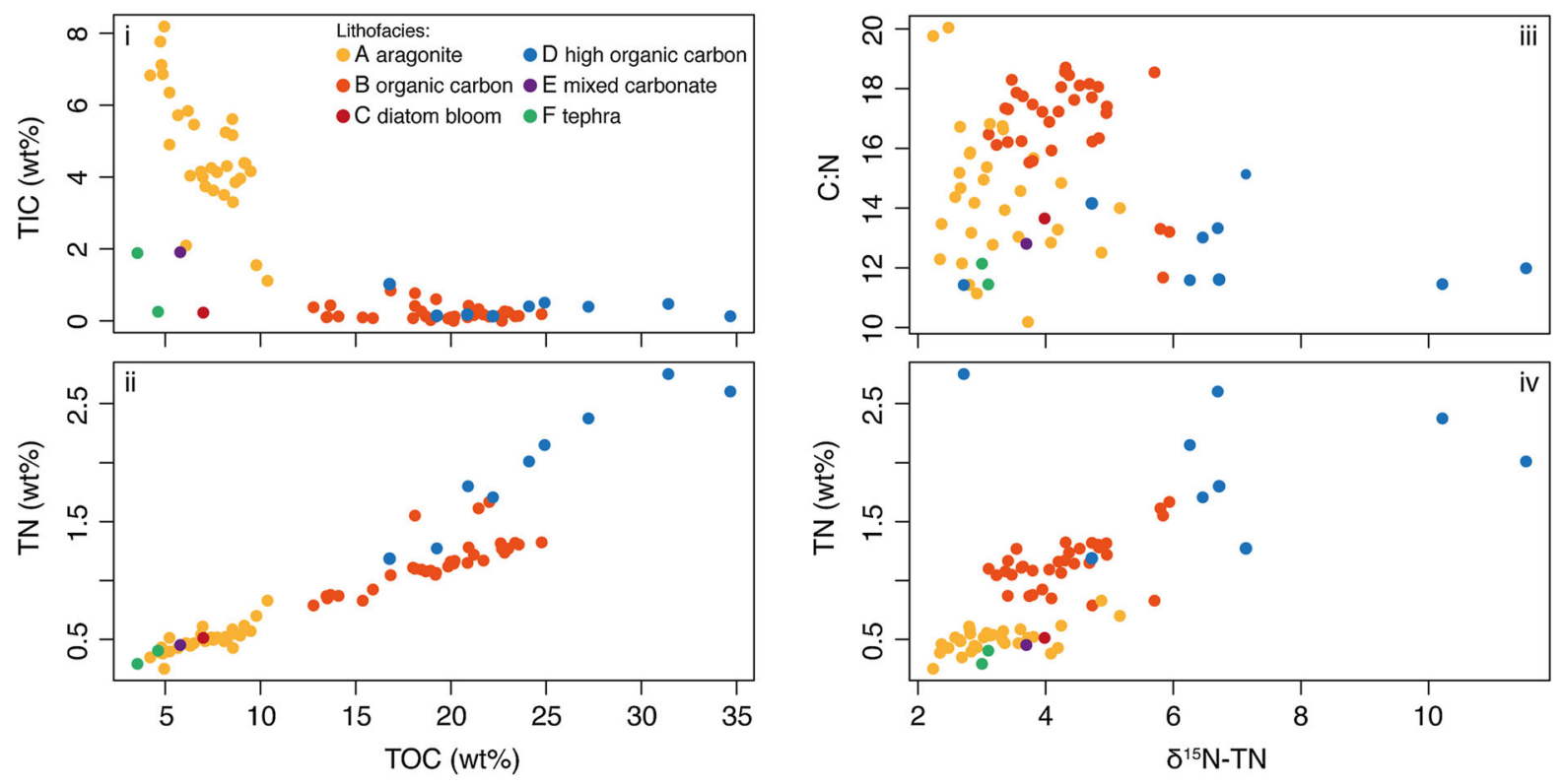

Fig. 5 Scatter plots of TIC, TOC, TN and ${ }^{15} \mathrm{~N}$ data. The data are coloured according to their lithofacies origin 


\section{Isotopes}

The ${ }^{15} \mathrm{~N}$ does not correlate with the fluctuations observed in $\mathrm{C}: \mathrm{N}$ in Fig. 5iii $(r=-0.02)$. This indicates that the observed ${ }^{15} \mathrm{~N}$ ratios in Fig. 3 do not represent changes in allochthonous versus autochthonous OM. Therefore, the variations in ${ }^{15} \mathrm{~N}$ are likely caused by lake-internal processes. Within lakes, denitrification and ammonification become increasingly dominant processes with an increasing $\mathrm{N}$ nutrient supply. Ultimately, the preferential elimination of isotopically light ${ }^{14} \mathrm{~N}$ by these metabolic pathways enriches ${ }^{15} \mathrm{~N}$ in the remaining DIN available for primary production (Struck et al. 2001). Alternatively, nitrogen fixation by cyanobacteria $(\sim 0 \%)$ during periods of reduced $\mathrm{N}$ nutrients will lower the ${ }^{15} \mathrm{~N}$ ratio of the OM (Olsen et al. 2013). These metabolic effects of ${ }^{15} \mathrm{~N}$ enrichment are underlined in KV10-04 by the positive correlation observed in Fig. 5iv $(r=0.7)$, where deviations from the trend are the highest within the D lithofacies. Within the D lithofacies, the ${ }^{15} \mathrm{~N}$ begins to increase near the top of the deposited layer at depths where the \% TOC begins to decrease (Fig. 3).

\section{Seismic stratigraphy}

The penetration, and therefore the achievable seismic stratigraphy, at the location of KV10-04 was poor

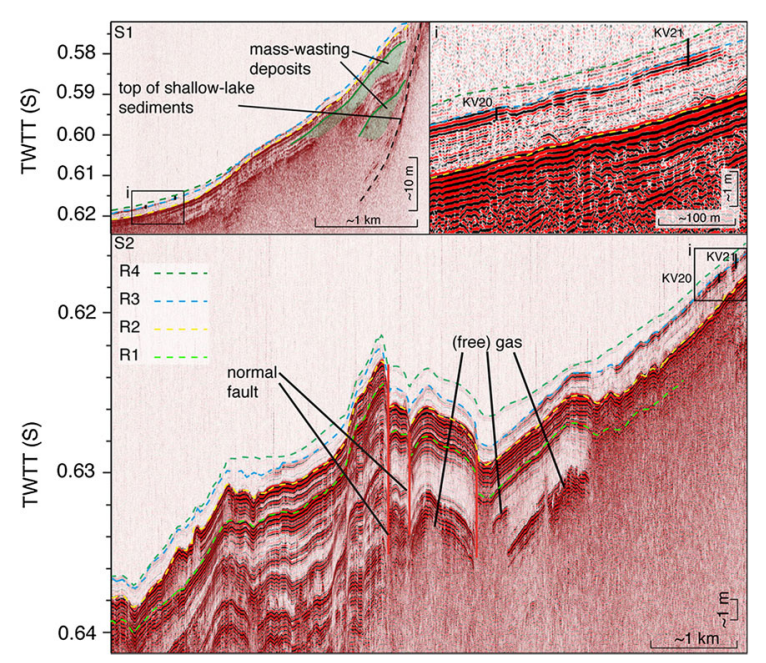

Fig. 6 Seismic profiles S1 and S2 in Fig. 1. The vertical and horizontal scales are located in the lower corner of each frame. Annotations are explained within the text owing to the gas content and steep slopes of the ridge observed here. However, the stratigraphy along seismic lines $\mathrm{S} 1$ and $\mathrm{S} 2$ in Fig. 6 provides a lateral sedimentologic dimension to the sediment cores KV10-20, 21, and core \#10 (Fig. 1). As a consequence of the similar depth and nearby location of core \#10 to our seismic profiles (Fig. 1), we can extrapolate the lithofacies observed in this core in Fig. 4 to the seismic stratigraphy in Fig. 6.

The prominent reflections $\mathrm{R} 1-\mathrm{R} 4$ traced in the seismic data in Fig. 6 refer to the lithology of core \#10 that are also marked R1-R4 in Fig. 4. The reflection R4 in Fig. 6 is the sediment-water interface represented by the top of the core KV10-04. The tephra layer F1 in KV10-04 aligns to the tephra layer in KV10-20 and -21 , and R3 in core \#10. The seismic-unit between reflections $\mathrm{R} 4$ and $\mathrm{R} 3$ is semi-transparent, and its lateral extension changes thickness and evens out the morphology in the deep basin (Fig. 6).

The high-amplitude reflection R2 in Fig. 6 corresponds to tephra layer R2 observed in core \#10 in Fig. 4. The tephra layers R3 and R2 were deposited at $\sim 1$ and $5 \mathrm{ka}$, respectively, according to Hecky and Degens (1973). Either a gas-eruption or lake-mixing event is postulated to have occurred at the time of their deposition (Haberyan and Hecky 1987). Both tephra layers mark the abrupt termination of laminated aragonite-OM alternations (lithofacies A in Fig. 4). Furthermore, these layers coincide with the bottom of a transparent seismic facies, with varying thickness, observed in Fig. 6.

The reflection R1 in Fig. 6 corresponds to the tephra layer R1 that forms the base of core \#10 in Fig. 4. This tephra layer was postulated to have been deposited during the increased volcanic activity in the Kivu Basin, which dammed the lake to the north $\sim 10 \mathrm{ka}$ (Ross et al. 2014).

\section{Discussion}

Significance of aragonite/OM laminations

The mixolimnion in Lake Kivu is oversaturated with respect to $\mathrm{CO}_{2}$ (Borges et al. 2012), and mixing in the dry season results in aragonite precipitation from $\mathrm{CO}_{2}$ degassing and a concomitant increase in $\mathrm{pH}$. This is manifested in the sediment-trap data collected by Pasche et al. (2010), where the highest amount of 
carbonate deposition is observed in June at the onset of the dry season. Within the sediment, there have been three shifts within the last $\sim 10 \mathrm{ka}$ from high OC to aragonite/OM laminations (from lithofacies $\mathrm{B}$ to $\mathrm{A}$; Fig. 4). The most recent onset of carbonate preservation in the sediment was initiated in 1976 at $9.5 \mathrm{~cm}$ core depth in KV10-04 (A1; Fig. 3), and persists today. Layer A1 in conjunction with the additional carbonate layers observed below this depth in KV10-04 and core \#10 beginning at 108 and $280 \mathrm{~cm}$ depth (Fig. 4) does not support the conclusions that carbonate preservation is a consequence of climate aridity causing the lake to mix, or of a monimolimnion that preexisted corrosive hydrothermal activity (Degens et al. 1973; Hecky and Degens 1973), or of anthropogenic changes to the catchment (Pasche et al. 2010). Although the current drought-like conditions in the Kivu Basin may be a factor influencing carbonate preservation, the observed stratification in the lake indicates that preservation is not a consequence of lake mixing. Additionally, the present-day monimolimnion is corrosive from ongoing hydrothermal activity, and the observations of prehistoric carbonate preservation cycling eliminate the anthropogenichypothesis.

We posit that carbonate preservation in the sediment is the product of an increase in alkalinity and $\mathrm{CO}_{2}$ in the monimolimnion from hydrothermal SGD culminating in a high dissolved inorganic carbon (DIC), and therefore a $\mathrm{CO}_{3}^{2-}$ concentration that eventually favours aragonite preservation (Ross et al. 2015). Since the onset of measurements conducted by Damas (1937), a 5-mM increase in alkalinity below $300 \mathrm{~m}$ depth has been observed. Such an increase in alkalinity alongside reducing reactions that occur in the monimolimnion, e.g. $\mathrm{SO}_{4}^{2-}$ reduction to $\mathrm{H}_{2} \mathrm{~S}$, will shift the DIC equilibrium to the saturation threshold of $\mathrm{CaCO}_{3}$ over time. This shift could hypothetically produce the sudden onset of carbonate preservation that we observe at lithofacies A2 and A1 in Fig. 3, if the monimolimnion is near the equivalence point of either $\mathrm{HCO}_{3}^{-}$or $\mathrm{CO}_{3}^{2-}$. The idea that the $\mathrm{CaCO}_{3}$ saturation varies with depth and time in Lake Kivu is synonymous to the changes in the lysocline and the aragonite compensation depth in the deep ocean (Zeebe and Westbroek 2003). The present lysocline in Lake Kivu appears within the first density gradient beneath the mixolimnion (Pasche et al. 2009).
Intense hydrothermal activity or subaquatic volcanism will increase the flux of $\mathrm{CO}_{2}$ and other acidic gases such as $\mathrm{SO}_{2}$ into the lake, and increase the thermal energy in the monimolimnion (Carey et al. 2013). As a consequence $\mathrm{CO}_{2}$ could become saturated and be expelled from the monimolimnion, thereby decreasing the total DIC in the lake and lowering the overall alkalinity as an effect of complete mixing. These gases, in addition to oxidation reactions that are likely associated with a lake eruption, will lower the $\mathrm{pH}$ with the net effect being carbonate dissolution. This scenario could explain the abrupt termination of the aragonite laminae at the tephra layers R2 and R3/ F1 (Figs. 3, 4). The abrupt termination of the carbonate layer corresponding to a tephra layer suggests the interplay between subaquatic volcanic activity and carbonate preservation in the sediment. Following the partial to complete obliteration of the stratification in Lake Kivu that might have occurred at these tephra layers, the ongoing hydrothermal SGD into the monimolimnion, and the cold SGD above the main pycnocline at $260 \mathrm{~m}$ depth, would reinitiate the stratification in the lake almost immediately (Ross et al. 2015; Schmid et al. 2012). The subsequent phases of carbonate preservation would be delayed compared to the increased SGD input, until the carbonate concentration in the water column reaches its saturation threshold. The preservation of carbonates in lithofacies A2 may have required more hydrothermal contribution than that resulting in A1, as a consequence of the already high alkalinity in the lake following a mixing event.

\section{Origin of event layers}

The lithofacies C, D, E, and F in KV10-04 represent geochemical changes in the mixolimnion at the time of their deposition (Fig. 3). We assume that the rate of sediment deposition in KV10-04 likely changed within an order of magnitude at the depth of these lithofacies. These layers are also observed by Pasche et al. (2010) in cores Kivu-06 and Kivu-07 taken from the Main Basin (Fig. 1). We suggest that punctuations in high productivity culminate in the $\mathrm{C}$ and $\mathrm{D}$ lithofacies, which are an effect of top-down versus bottom-up mixing events, respectively.

Layer $\mathrm{C} 1$ at $13 \mathrm{~cm}$ core depth in Fig. 3 is characterized by a high diatom content and coincides 
with a peak in BSi and Mn:Fe. This is indicative of a diatom bloom due to increased mixing-depth in the dry season resulting in increased production, but would not have reached a depth more significant than the peak in $\mathrm{Mn}^{2+}$ observed just below the oxycline in the water column. The high $\mathrm{Mn}: \mathrm{Fe}$ suggests oxygen diffusion and precipitation of $\mathrm{MnO}$ minerals, indicating top-down mixing. This contrasts with D layers, which lack clear indications of metal oxides. The D lithofacies are the result of enhanced OM production and contain up to $31 \%$ TOC (ESM2). The present-day OM preservation in Lake Kivu is $10-20 \%$ with most of the degradation occurring during early diagenesis (Pasche et al. 2010). We postulate that the D lithofacies in KV10-04 were produced by single events that resulted in a high flux of nutrients into the mixolimnion from below, consequently yielding a high productivity and an increase in OM flux and preservation. Such an event could be caused by a buoyant hydrothermal plume (Woods 2010), which would entrain nutrients from below and could penetrate the mixolimnion.

Since the residence time of the nutrients in the monimolimnion of the lake is on the order of thousands of years (Schmid et al. 2005), the isotopic composition of the nutrients supplied to the surface layer is likely constant over shorter time scales. Therefore changes to the internal nutrient recycling, such as the preferential assimilation of isotopically light ${ }^{14} \mathrm{~N}$ during phytoplankton growth, will result in the greatest fractionation between the DIN and the OM when nitrogen is not limiting (Olsen et al. 2012). We propose that the observed peaks in ${ }^{15} \mathrm{~N}$ ratios at depths corresponding to the top of the D lithofacies in KV1004 (Fig. 3), Kivu-06, and Kivu-07 reflect a strong increase of $\mathrm{N}$-nutrient input into the mixolimnion. Increased OM production is concomitant with increased denitrification and ammonification, which could continuously deplete the nutrient pool in the mixolimnion while enriching it in ${ }^{15} \mathrm{~N}$. This results in a delayed peak in ${ }^{15} \mathrm{~N}$ in Fig. 3 relative to the peak in TN within the $\mathrm{D}$ lithofacies. The peaks in ${ }^{15} \mathrm{~N}$ observed in layers D1, D2, and D3 are enriched by a factor $(\epsilon)$ of $1.7,1.5$, and 2.4, respectively (ESM2). We hypothesize that the D layers are formed as a result of single events, which are of volcanic origin based on that layers D3 and D1 in KV10-04 overlay tephra deposits F1, and E1, respectively. Significant volcanic events would have resulted in oversaturation of the gases in the lake and degassing to the atmosphere as suggested by our biogeochemical data. An induced oversaturation of gases is consequent of the high DIC concentrations that are inferred during periods of carbonate preservation discerned from the presence of the A lithofacies. These eruptions result in an abrupt change in the geochemical depositional regime initiating the B lithofacies (Fig. 4).

To further investigate the hypothesis that a bottomup mixing event occurred at the D lithofacies, rather than a top-down mixing event, we compared the regional climate-proxy records that have revealed periods of intense aridity or temperature cooling in Lake Edward (Russell and Johnson 2005, 2007), Tanganyika (Tierney et al. 2010), and Malawi (Johnson et al. 2002) with the record observed in Lake Kivu in Fig. 3 and age models in Fig. 2. We do not observe any correlation in these records to the D lithofacies observed in KV10-04, however, the temporal resolution may not be refined enough to define a mixingevent in Lake Kivu. Furthermore, we calculated the mixing depth, and corresponding temperatures and heat dissipation required to achieve this mixing depth in Lake Kivu and Lake Tanganyika, in order to entrain sufficient nutrients from below to produce the D lithofacies observed (ESM3). These calculations resulted in heat dissipation and lake surface temperature constraints that would completely overturn Lake Tanganyika, where the density stratification is much weaker (Verburg et al. 2003). Such an indication of mixing has not been observed in the relatively refined sediment record of Lake Tanganyika, however this possibility has not been investigated in detail. Additional wind-induced mixing models also indicated the necessity of continuous, strong winds of $>15$ $\mathrm{m} \mathrm{s}^{-1}$ for an extended period of time in order to mix to a depth below 80 meters in Lake Kivu (Aaberg 2013).

Corresponding D lithofacies were originally observed by Hecky and Degens (1973) in core \#10 (Fig. 4 ), and considered to be indicators of hydrothermal discharge. Hecky and Degens (1973) predicted that these layers were composed almost entirely of algal biomass, which was later confirmed by Al-Mutlaq et al. (2008). Degens et al. (1973) describe the D lithofacies as synonymous to sapropels observed in the anoxic ocean (Calvert et al. 1992). They conclude that an increased frequency of the 
D lithofacies is associated with wetter climatic conditions and hydrothermal activity, which resulted in the thermohaline stratification present today. Here we confirm that the D lithofacies have a high OM content from autochthonous origin, are low in diatoms, and enriched in ${ }^{15} \mathrm{~N}$ (Fig. 3). We also suggest that these layers are analogous to the sapropels observed in the anoxic ocean, where the enriched ${ }^{15} \mathrm{~N}$ and high OC content are a result of denitrification (Struck et al. 2001). Furthermore, we hypothesize that these layers are a consequence of episodic intense hydrothermal activity.

\section{Paleoenvironmental reconstruction}

Given the cumulative data collected from the cores taken below the mixolimnion (Fig. 1), the past sedimentological history of Lake Kivu since the lake-level rise in the late Pleistocene can be reconstructed. Core \#10 terminated in tephra layer R1 hypothesized to be deposited during the lake-level rise $\sim 10 \mathrm{ka}$. The age model constructed by Degens et al. (1973) yielded a sedimentation rate of $0.3 \mathrm{~mm}$ year $^{-1}$ for this core, where this rate was calculated from only one sample younger than $10 \mathrm{cal}$ kyr BP (6200 cal year BP; Fig. 6). Furthermore, the radiocarbon analysis was conducted on bulk-OM that could result in anomalously old ages from the reservoir effect of old carbon. From Age model 1 and 2 (Fig. 2) an age of $\sim 9.3-$ $6.6 \mathrm{ka}$ for layer $\mathrm{R} 1$ is calculated. This age range correlates to the first evidence of overflow via the Ruzizi River into Lake Tanganyika at $\sim 8$ ka (Felton et al. 2007).

The high preservation of carbonate beginning in core \#10 at $280 \mathrm{~cm}$ (Fig. 4) is dated to 7.6-5.4 ka, and was abruptly terminated at tephra layer R2, at $4.2-3 \mathrm{ka}$ $(160 \mathrm{~cm}$; Fig. 4). This period of carbonate preservation corresponds to the increase in the $\mathrm{Ca} / \mathrm{Al}$ observed by Felton et al. (2007) in the Lake Tanganyika sediment record at $<\sim 4 \mathrm{ka}$. We suggest that this carbonate was preserved in the sediment as a consequence of increasing DIC in the monimolimnion, and not due to climatic changes that might have led to a lake-level low stand and a closed basin, as suggested by Haberyan and Hecky (1987) and Hecky and Degens (1973). However, there were periods of intense aridity that are recorded in other lakes in East Africa during the mid-Holocene, including Lake Edward from
5400-2000 ka (Russell et al. 2003), Lake Turkana at 5270 cal year BP (Garcin et al. 2012), and Lake Chala from 5.9 to $4.7 \mathrm{cal} \mathrm{kyr} \mathrm{BP}$ and again from 3.6 to 3.0 cal kyr BP (Verschuren et al. 2009). In general, the time period after $\sim 5 \mathrm{ka}$ was drier than the early Holocene in East Africa, termed the 'African Humid Period'. The 2nd carbonate layer was initiated at $110 \mathrm{~cm}$ corresponding to $2.8-2 \mathrm{ka}$ (A2; Fig. 4). This date coincides with a peak in aridity documented in Lake Edward at 2 cal kyr BP (Russell et al. 2003). However, layer A2 spans the onset of a wetter climate beginning $\sim 1.7$ ka documented in both Lake Edward and Tanganyika (Stager et al. 2009). This carbonate layer was also abruptly terminated, at $1.2 \mathrm{ka}$ (Fig. 2, Age model 1) or at no later than $765 \mathrm{cal}$ year BP (Fig. 2, Age model 2). Finally, the onset of the carbonate layer that is currently preserved in the sediments of the monimolimnion (A1; Fig. 3) was not initiated until $1976 \mathrm{AD}$, and corresponds to a large peak in $\mathrm{Sr}$ and $\mathrm{Zr}$ (Figs. 2, 3, respectively). This change in depositional regime might indicate a controlling effect of hydrothermal activity corresponding to the 1977 Nyiragongo eruption (Tazieff 1977).

The D lithofacies observed in core \#10 (above layer R2; Fig. 4) and KV10-04 (D3 and D1 above layer R3/ F1 and E1, respectively; Fig. 4) overlay tephra layers, and could therefore correspond to large inputs of nutrients into the mixolimnion as a consequence of subaquatic volcanic activity in the monimolimnion. Furthermore, these subaquatic volcanic pulses likely resulted in a gas eruption, and subsequently a lakemixing event, if they materialized with high DIC concentrations in the monimolimnion. The last mixing event occurred at $1.2 \mathrm{ka}$ or no later then $765 \mathrm{cal} \mathrm{yr} \mathrm{BP}$ where a large peak in $\mathrm{Ti}$ and $\mathrm{Fe}$ is observed in $\mathrm{KV} 10$ 04 at $49.5 \mathrm{~cm}$ depth. Fe and Mn would be oxidized upon a lake-mixing event, and a concave peak in $\mathrm{Mn}: \mathrm{Fe}$ observed at F1 is likely a consequence of the higher solubility of $\mathrm{Mn}$ at a low $\mathrm{pH}$. The large influx of nutrients into the monimolimnion upon lake mixing results in the deposition of the high OC layer D3. The ensuing layer B4 ends abruptly with the high OC layer D2, which likely also corresponds to subaquatic volcanic activity. The high authigenic Fe recorded in the following layer B3 and B2 could be due to wetter climatic conditions that would result in increased SGD into the monimolimnion (Pasche et al. 2009). Layers B3 and B2 are separated by layer D1 at $\sim 400 \mathrm{cal} \mathrm{yr}$ BP (Fig. 2), which marks the last indication of intense 
hydrothermal activity. This date corresponds to an increase in $\mathrm{Ti}$ into the lake up until the present. A Ti increase was also recorded in core Kivu-06 by Pasche et al. (2010) and attributed to changes in the catchment including deforestation and heightened population. This explanation seems likely given that the most significant input of Ti recorded outside of the tephra layers in KV10-04 has been within the last 30 years (down to $8 \mathrm{~cm}$ depth; Fig. 3).

Two anomalously old radiocarbon samples dated 10 and $11 \mathrm{cal} \mathrm{kyr} \mathrm{BP}$ were acquired from layer B4 in core KV10-04 and Kivu-07 (Fig. 1). The correlating B4-lithofacies in Kivu-06 was determined to have an unusually low abundance of plankton (Pasche et al. 2010). Additionally, a third radiocarbon sample with a date of 11 cal kyr BP was acquired from the massmovement deposit in KV10-21. The appearance of three samples dated $\sim 10$ cal kyr BP (Fig. 2) is attributed to the high influx of terrestrial material with the lake-level rise in the late Holocene. However, massive sediment mobilization is the only reasonable explanation for the presence of terrestrial macrofossils that are $>10 \mathrm{cal}$ kyr BP at less than $50 \mathrm{~cm}$ depth in three cores from three locations. We suggest that these anomalously old dates are from terrestrial macrofossils that remain buoyant in the water column following sediment mobilization concomitant with seismic events or a lake eruption. Such reoccurring events could account for the observation of these macrofossils in the upper layers of the sediment cores.

The sediment-mixed tephra layer observed in $\mathrm{KV} 10-20$, and -21 correlates to the reflection $\mathrm{R} 3$ in the seismic profile in Fig. 6, across the basin to KV1019 (52 cm core depth; Fig. 2), and to the tephra layer F1 in KV10-04 (Fig. 3). The ensuing transparent seismic facies observed in Fig. 6 above this layer is postulated to be mobilized sediment as an effect of either seismic events corresponding to basin volcanic activity, or a gas eruption from the deepwater. The resulting basin-wide transparent seismic facies is mapped in ESM4. A total of two transparent seismic facies are observed in Fig. 6 overlying what appears to correspond to layers R3 and R2 in Fig. 4. The variation in thickness observed within this facies in ESM4 could be formed by a gravitational sediment focusing of mass movements upon a lake-wide event. This phenomenon was also observed in Lake Nyos by Freeth and Rex (2000) following its eruption as an effect of gas oversaturation in 1986.

\section{Conclusions}

From the analysis of the sediment stratigraphy, lithology, and geochemistry of sediment cores taken in the Main Basin (Fig. 1), we are able to deduce the major environmental changes that have occurred since the onset of increased volcanic activity and lake-level rise at $\sim 10 \mathrm{ka}$. From these results, we hypothesize that the evolution from OC to aragonite/OM-laminae in the sediment, which is then abruptly terminated at a tephra layer, is coeval with SGD and subaquatic volcanic activity within the monimolimnion. This sequence of events has occurred twice following $\sim 10 \mathrm{ka}$, presumably due to gas eruptions as a consequence of volcanic activity at $\sim 5$ and at $\sim 1$ ka. Furthermore, pulses in subaquatic volcanism that resulted in buoyant hydrothermal plumes have occurred no later than 400 cal year BP. The present-day carbonate saturation in the monimolimnion since the 1970s implies that there has been a recent increase in hydrothermal activity. Given that indications of a gas eruption from the lake have only occurred at periods of carbonate saturation, these results highlight the importance of monitoring subaquatic volcanic activity in Lake Kivu.

Acknowledgments Fieldwork for this project was conducted on Lake Kivu with no special permissions because the study was part of a joint scientific project involving the University of Rwanda (former Kigali Institute of Science and Technology) and the Institut Supérieur Pdagogique de Bukavu (DR Congo). We would like to thank W. Versteeg, K. De Rycker, N. Pasche, C. Balagizi, and the crew of the RV Gloria for their assistance during the sampling campaign in Africa. For the sedimentary analysis back in Europe, we would like to thank A. Zwyssig, I. Brunner, C. Schubert, P. Zigah, S. Robert., M. Morellon, and J. Frigola. Furthermore, we are very grateful for the scientific discussions and intellectual support provided by A. Wüest, B. Wehrli, A. Brand, M. Hilbe, M. De Batist, J. Moernaut, L. Och, H. Vogel, and N. Dubois. We are additionally thankful for the helpful comments given by the editors J. Holmes and T. J. Whitmore, and the anonymous reviewers. Lastly, we are honoured to have worked with Gijs Nobbe for support with the geochemical and isotope analysis; whose uplifting, patient, and kind demeanour will remain in our memory. This project was financially supported by the Swiss National Science Foundation and the Swiss Agency for the Development and Cooperation under grant IZ70Z0-123923.

\section{References}

Aaberg AA (2013) Warming and stratification changes in Lake Kivu, East Africa. Master's thesis, University of Minnesota Al-Mutlaq KF, Standley LJ, Simoneit BR (2008) Composition and sources of extractable organic matter from a sediment 
core in Lake Kivu. East African rift valley. Appl Geochem 23(5):1023-1040

Appleby P, Oldfield F (1978) The calculation of lead-210 dates assuming a constant rate of supply of unsupported ${ }^{210} \mathrm{~Pb}$ to the sediment. Catena 5(1):1-8

Borges AV, Bouillon S, Abril G, Delille B, Poirier D, Commarieu MV, Lepoint G, Morana C, Champenois W, Servais P, Descy JP, Darchambeau F (2012) Variability of carbon dioxide and methane in the epilimnion of Lake Kivu. In: Descy JP, Darchambeau F, Schmid M (eds) Lake Kivu: limnology and biogeochemistry of a tropical great lake, Springer, 4, pp 47-66

Brown ET, Johnson TC (2005) Coherence between tropical East African and South American records of the Little Ice Age. Geochem Geophy Geosy 6(12):Q12005

Calvert S, Nielsen B, Fontugne M (1992) Evidence from nitrogen isotope ratios for enhanced productivity during formation of eastern Mediterranean sapropels. Nature 359:223-225

Carey S, Nomikou P, Bell KC, Lilley M, Lupton J, Roman C, Stathopoulou E, Bejelou K, Ballard R (2013) $\mathrm{CO}_{2}$ degassing from hydrothermal vents at Kolumbo submarine volcano, Greece, and the accumulation of acidic crater water. Geology 41(9):1035-1038

Damas H (1937) La stratification thermique et chimique des lacs Kivu, Edourd et Ndalaga (Congo Belge). Verhandlungen der Internationalen Vereinigung für Theoretische und Angewandte Limnologie 8(3):51-68

Darchambeau F, Sarmento H, Descy JP (2014) Primary production in a tropical large lake: the role of phytoplankton composition. Sci Total Environ 473:178-188

Degens ET, Kulbicki G (1973) Hydrothermal origin of metals in some East African rift lakes. Miner Deposita 8(4):388-404

Degens ET, von Herzen RP, Wong HK, Deuser WG, Jannasch HW (1973) Lake Kivu: structure, chemistry and biology of an East African rift lake. Geol Rundsch 62(1):245-277

Felton AA, Russell JM, Cohen AS, Baker ME, Chesley JT, Lezzar KE, McGlue MM, Pigati JS, Quade J, Stager JC, Tiercelin JJ (2007) Paleolimnological evidence for the onset and termination of glacial aridity from Lake Tanganyika. Tropical East Africa. Palaeogeogr Palaeocl 252(3):405-423

Freeth S, Rex D (2000) Constraints on the age of Lake Nyos. Cameroon. J Volcanol Geoth Res 97(1):261-269

Garcin Y, Melnick D, Strecker MR, Olago D, Tiercelin JJ (2012) East African mid-Holocene wet-dry transition recorded in palaeo-shorelines of Lake Turkana, northern Kenya Rift. Earth Planet Sc Lett 331-332:322-334

Haberyan KA, Hecky RE (1987) The late Pleistocene and Holocene stratigraphy and paleolimnology of Lakes Kivu and Tanganyika. Palaeogeogr Palaeocl 61:169-197

Hecky RE, Degens ET (1973) Late Pleistocene-Holocene chemical stratigraphy and paleolimnology of the Rift Valley lakes of Central Africa. WHOI technical report, Woods Hole Oceanographic Institution, Woods Hole, Mass

Johnson TC, Brown ET, McManus J, Barry S, Barker P, Gasse F (2002) A high-resolution paleoclimate record spanning the past 25,000 years in southern East Africa. Science 296(5565):113-132

Muvundja FA, Wüest A, Isumbisho M, Kaningini MB, Pasche N, Rinta P, Schmid M (2014) Modelling Lake Kivu water level variations over the last seven decades. Limnologica 47:21-33

Olsen J, Anderson NJ, Knudsen MF (2012) Variability of the North Atlantic Oscillation over the past 5200 years. Nat Geosci 5(2012):808-812

Olsen J, Anderson NJ, Leng MJ (2013) Limnological controls on stable isotope records of late-Holocene palaeoenvironment change in SW Greenland: a paired lake study. Quaternary Sci Rev 66(213):85-95

Pasche N, Dinkel C, Müller B, Schmid M, Wüest A, Wehrli B (2009) Physical and bio-geochemical limits to internal nutrient loading of meromictic Lake Kivu. Limnol Oceanogr 54(6):1863-1873

Pasche N, Alunga G, Mills K, Muvundja F, Ryves DB, Schurter M, Wehrli B, Schmid M (2010) Abrupt onset of carbonate deposition in Lake Kivu during the 1960s: response to recent environmental changes. J Paleolimnol 44(4):931-946

Pasche N, Schmid M, Vazquez F, Schubert CJ, Wüest A, Kessler JD, Pack MA, Reeburgh WS, Bürgmann H (2011) Methane sources and sinks in Lake Kivu. J Geophys Res 116(G3):G03,006

Powers LA, Johnson TC, Werne JP, Castañeda IS, Hopmans EC, Sinninghe Damsté JS, Schouten S (2011) Organic geochemical records of environmental variability in Lake Malawi during the last 700 years, part I: the TEX $_{86}$ temperature record. Palaeogeogr Palaeocl 303(1):133-139

Ramsey CB (2009) Bayesian analysis of radiocarbon dates. Radiocarbon 51(1):337-360

Ross KA, Smets B, De Batist M, Hilbe M, Schmid M, Anselmetti FS (2014) Lake-level rise in the late Pleistocene and active subaquatic volcanism since the Holocene form the current state of Lake Kivu; East African Rift. Geomorphology 221:274-285. doi:10.1016/j.geomorph.2014.05. 010

Ross KA, Gafasi A, Gashugi E, Wüest A, Schmid M (2015) Characterisation of the subaquatic groundwater discharge that maintains the permanent stratification within Lake Kivu. East Africa. PloS one 10.3:e121217

Russell J, Johnson T (2007) Little Ice Age drought in equatorial Africa: intertropical convergence zone migrations and El Niño-Southern Oscillation variability. Geology 35(1): 21-24

Russell JM, Johnson TC (2005) A high-resolution geochemical record from Lake Edward, Uganda Congo and the timing and causes of tropical African drought during the late Holocene. Quaternary Sci Rev 24(12):1375-1389

Russell JM, Johnson TC, Kelts KR, Lærdal T, Talbot MR (2003) An 11 000-year lithostratigraphic and paleohydrologic record from equatorial Africa: Lake Edward. UgandaCongo. Palaeogeogr Palaeocl 193(1):25-49

Sarmento H, Isumbisho M, Descy JP (2006) Phytoplankton ecology of Lake Kivu (eastern Africa). J Plankton Res 28(9):815-829

Sarmento H, Darchambeau F, Descy JP (2012) Phytoplankton of Lake Kivu. In: Descy JP, Darchambeau F, Schmid M (eds) Lake Kivu: limnology and biogeochemistry of a tropical great lake, Springer, 5, pp 67-83

Schmid M, Wüest A (2012) Stratification, mixing and transport processes in Lake Kivu. In: Descy JP, Darchambeau F, Schmid M (eds) Lake Kivu: limnology and biogeochemistry of a tropical great lake, Springer, 2, pp 13-29 
Schmid M, Tietze K, Halbwachs M, Lorke A, McGinnis D, Wüest A (2003) How hazardous is the gas accumulation in Lake Kivu? Arguments for a risk assessment in light of the Nyiragongo Volcano eruption of 2002. Acta Vulcanol 14/15(1/2):115-122

Schmid M, Halbwachs M, Wehrli B, Wüest A (2005) Weak mixing in Lake Kivu: new insights indicate increasing risk of uncontrolled gas eruption. Geochem Geophys Geosys 6:Q07009

Schmid M, Ross K, Wüest A (2012) Comment on an additional challenge of Lake Kivu in Central Africa-upward movement of the chemoclines by Finn Hirslund. J Limnol 71(2):330-334

Schoell M, Tietze K, Schoberth S (1988) Origin of methane in Lake Kivu (east-central Africa). Chem Geol 71(1):257-265

Smets B, Wauthier C, d'Oreye N (2010) A new map of the lava flow field of Nyamulagira (DR Congo) from satellite imagery. J Afr Earth Sci 58(5):778-786

Stager JC, Ryves D, Cumming BF, Meeker LD, Beer J (2005) Solar variability and the levels of Lake Victoria, East Africa, during the last millenium. J Paleolimnol 33(2):243-251

Stager JC, Cocquyt C, Bonnefille R, Weyhenmeyer C, Bowerman N (2009) A late holocene paleoclimatic history of Lake Tanganyika. East Africa. Quaternary Res 72(1):47-56

Stoffers P, Hecky RE (1978) Late Pleistocene-Holocene evolution of the Kivu-Tanganyika Basin. Modern Anc Lake Sediments 2:43-55

Struck U, Emeis KC, Voß M, Krom MD, Rau GH (2001) Biological productivity during sapropel S5 formation in the Eastern Mediterranean Sea: evidence from stable isotopes of nitrogen and carbon. Geochim Cosmochim Acta 65(19):3249-3266

Tazieff H (1977) An exceptional eruption: Mt. Niragongo, January 10th, 1977. B Volcanol 40(3):189-200

Tierney JE, Mayes MT, Meyer N, Johnson C, Swarzenski PW, Cohen AS, Russell JM (2010) Late-twentieth-century warming in Lake Tanganyika unprecedented since AD 500. Nat Geosci 3(6):422-425

Tierney JE, Smerdon JE, Anchukaitis KJ, Seager R (2013) Multidecadal variability in East African hydroclimate controlled by the Indian Ocean. Nature 493(7432):389-392

Verburg P, Hecky RE, Kling H (2003) Ecological consequences of a century of warming in Lake Tanganyika. Science 301(5632):505-507

Verschuren D, Damsté JSS, Moernaut J, Kristen I, Blaauw M, Fagot M, Haug GH, van Geel B, De Batist M, Barker P (2009) Half-precessional dynamics of monsoon rainfall near the East African Equator. Nature 462(7273):637-641

Vogel H, Meyer-Jacob C, Melles M, Brigham-Grette J, Andreev A, Wennrich V, Tarasov P, Rosén P (2013) Detailed insight into Arctic climatic variability during MIS 11c at Lake El'gygytgyn. NE Russia. Clim Past 9(4):1467-1479

Woods AW (2010) Turbulent plumes in nature. Annu Rev Fluid Mech 42:391-412

Zeebe RE, Westbroek P (2003) A simple model for the $\mathrm{CaCO}_{3}$ saturation state of the ocean: the "Strangelove", the "Neritan", and the "Cretan" Ocean. Geochem Geophy Geosy 4:GC000538 